\title{
EXAMINING THE PARTHIAN ART AND ARCHITECTURE AND THE IMPACT OF GREEK ART AND ARCHITECTURE
}

\section{Soha Nabaei ${ }^{1}$}

Elham Alipanahi ${ }^{2}$

\begin{abstract}
In this article, a brief look at the history of ancient Iranian art before Islam, its characteristics during the Parthian rule, and the study of the monuments left over from that period, especially the palaces and the influence of ancient Greek architecture on them. Parthian period, due to the succession of the Seleucids, the Greek and Iranian domination over the Greek culture and architecture were widespread in Iran, one of the most important periods of the history of Iran. The Parthian era culture is a culture that tries to dominate the remains of Greek civilization and culture to bring Iran to re-establish. Parthian win this battle and inspiring inventions and innovations of the Sassanid civilization and Islamic culture of Iran. Overall, what is interesting is the dramatic Parthian architecture are among the Porticoes wide open courtyard surrounded by
\end{abstract}

columns attached to the wall. Plaster Vonda colored object of interesting architectural elements farthest era of special features. The use of materials and the use of adobe bricks with mortar gained sharply. Perhaps one of the advantages of this new material, creating massive arch of the dome is first and then create a new architectural style were the architects of the Sassanid indebted. City maps with Hypoderm been carried out in some cities. But the main feature of the Parthian city circular design in cities such as Marv, Ctesiphon and Hart seen.

Keywords: Architecture, Parthian, Greece, Urban.

\section{Introduction}

Alexander the Great's overthrow of Iran and the extinction of the Achaemenid government completely

\footnotetext{
${ }^{1}$ M.A student, Department of Architecture, Islamic Azad University, Science and Research Branch, Tehran, Iran.

${ }^{2}$ Assistant Professor, Department of Architecture, University College of Rouzbahan, Sari, Iran. Corresponding Author Email: Msn.sirjan2019@gmail.com.
} 
undermined Iranian culture and civilization. The political revolution and the chaos of the country necessitated an important literary revolution. Parthian warrior and brave people who have been successful for five years a powerful empire across the Iranian Plateau run.Achaemenes defeat of Alexander, his successors continue the government, a combination of new features art culture eastern Greece was replaced by former Iranian cultural and historical features. Greek family relationship with the Orient, background and reasons for the favorable influence of culture between East and West created. The new culture emerging as an institution that Hellenistic culture (Hellenistic) became famous. In the course of mixing styles Greek and Persian practices of other nations ((Hellenistic architecture)) was created. However, the extent to which historians study the Parthian, GreekRoman attitude most have rejected the values of their special abilities become more obvious Parthian architectural survey and the influence of Greek architecture, the purpose of this article.

Forming parts people: Part Porta a branch of the Iranian people. The inscription of Darius $I$ of the
Achaemenes Inscription land on the "light" called. According Astra bun,Parthian leader was a man named Rask's Arish which later became part of the Parthian king's hypothetical ancestor.Part of the successors of Alexander the Macedonian government toppled Achaemenes (Seleucid), and have a strong government and a huge back for five centuries are founded. Parthian city of Nysa first capital (near Ashgabat) Turkmenistan, the second capital city of one hundred gates that it hecatomb pelisse said police in southwest Dagan and the third city of Ctesiphon on the Tigris and the other is Seleucia.

Parthian era architecture: Parthian architecture developed very different given.Marina this period were the heirs of different traditions, traditions of Central Asia on the one hand with them and on the other hand saw an Iranian native architectural features.The collection of Greek traditions should also be noted that during the rule of was common in Iran. Parthian architectural style as the other continued and consolidated. Parthian architecture combined Greek and Persian elements in the development of a unique 
architectural work. The Parthians in 123 BC. The following is information about a wide architecture Party begins. The ruins of a great palace of the second century AD Altar, Iraq, if they cannot see party technologies, at least enough to know that Botanysatdad open party.The main facade is made of stone cut with two large patio. Two smaller rooms Dashawn beat the symbol and may have two floors. The room is small arch in Altar apparently been a place of worship.The excavations that took place in different parts of the remains of the Parthians and then the style of the past were builtyou can specify the architecture and features, including: Maximum use of materials such as canvas binding of stone, adobe and plaster cooked one of the architectural features of aggregate Party (shaved, aging, carcass) and adobe in the body and cover. Construction materials used during the Parthian and Sasanian time more cleanly shaven stones mostly of adobe, clay is. To decorate buildings and blue glazed tiles and plaster coating (baked and crushed stone (stone)) was used. The emerging phenomenon in the Parthian period plaster decoration was for the first time, the material is flexible and easy access to, and the material was suitable to perform different tasks. Which was widespread relief that a combination of Greek and Achaemenes style. More because of the abundance of the mineral gypsum plaster art boom and ease of working with this method is that the use of decorative has caused. At the time, mortar, plaster on the wall easily and quickly was drawn and it was hard. Since the Achaemenes for decorating the building of masonry and stone was used for the construction of parts of the Median of engraved bricks were used. Very good use of advanced techniques and Ivan arch and dome of the dome using ecological materials out:Parthian architectural style before the wooden roof against climate change, such as humidity, corrosion or other risks such as fire and life cannot be durable materials to cover the arc and arch were drawn. Buildings on top of the style of Iranian construction of the Parthian dynasty start.In fact, two of the dome arch buildings known to date in country, One of the first king of the Sassanid palace was built in the late Parthian period and the other House, Mount Khawaja in Sistani that more resembled a Greek buildings to the Iranian Amby.Parthian 
architecture arch rocking the arc and Richen with stone slates and decorative relief work routine and sometimes you had a column. -Party style buildings designed after the invention of the dome, a mixture of the porch, the room is domed chamber. And in the house, porch to put innovation into the next period's architecture was transferred. As open space covered porch on the one hand and the connecting space is outside, in addition to the hours of the day and seasons of the year is habitable and operation. - The most important architectural parties, abandon the use columns to keep the rectangular room ceilings and instead beat arch from one side to the courtyard or courtyard of the network that had been made. Parthian unlike the Achaemenes (the stone) and Mud (using wooden structure) to hold the roof, columns and the porch went ahead for the first time in the Iranian and Greek art from Venture hidden. The building houses the central life plan was to explore more areas have been identified in Mesopotamia, the system architecture. Central to the plan is an excellent example of the life of Ivan led standard, has been identified in the State House. -Do not avoid and alpine glory in this long porch and covered by a dome structures with short and long run by Iranian architects have a special skill. It works like House of buildings can be Firuz Abad and harvestman especially huge deficit arch named. -The tremendous variety of designs: Another Party architectural features of the buildings is diverse and non-uniform, So that the building cannot have that same map,In contrast, the European churches and other buildings in particular are often the same plan.Remains of the Parthian period, including the State House, the Palace of Harte (Herten), which in Arabic is called Altar, Throne of Solomon Temple, Temple is in Kandahar. -Using mortar and asphalt that it could create large architectural spaces, Char bitumen mortar (mortar) is comprised of: lime milk, washed and ground clay, plaster half-baked and half beaten, Gaurs (sand grains such as millet), rock sugar, syrup made of grapes or dates, sometimes goat hair camel Yapshm have been added to the mortar. Stone mortar were not used, because the Parthians were refractory clay and brick mortar.

\section{Introducing Greek Architecture:}


The houses of the ancient Greeks were devoid of any selfdeprecating ornaments, the Greeks did not have royal houses, and they performed their religious rituals in the open air, and the architects were tireless.

Their very important buildings were originally built as simple shrines to preserve the statues of their gods. More and more attention was being paid to the construction of these buildings every day, until they strongly decided to embody the attributes of each god in the buildings or shrines themselves. The sculpture played its part in this transformation; the Greeks also considered the building itself to be an abstract form, with a power to embody human traits.

They emphasized the pervasive importance of the stately temple and its inspiring role in public life by choosing a high point often over a hill overlooking the city (Acropolis) for its building (Figure 1).

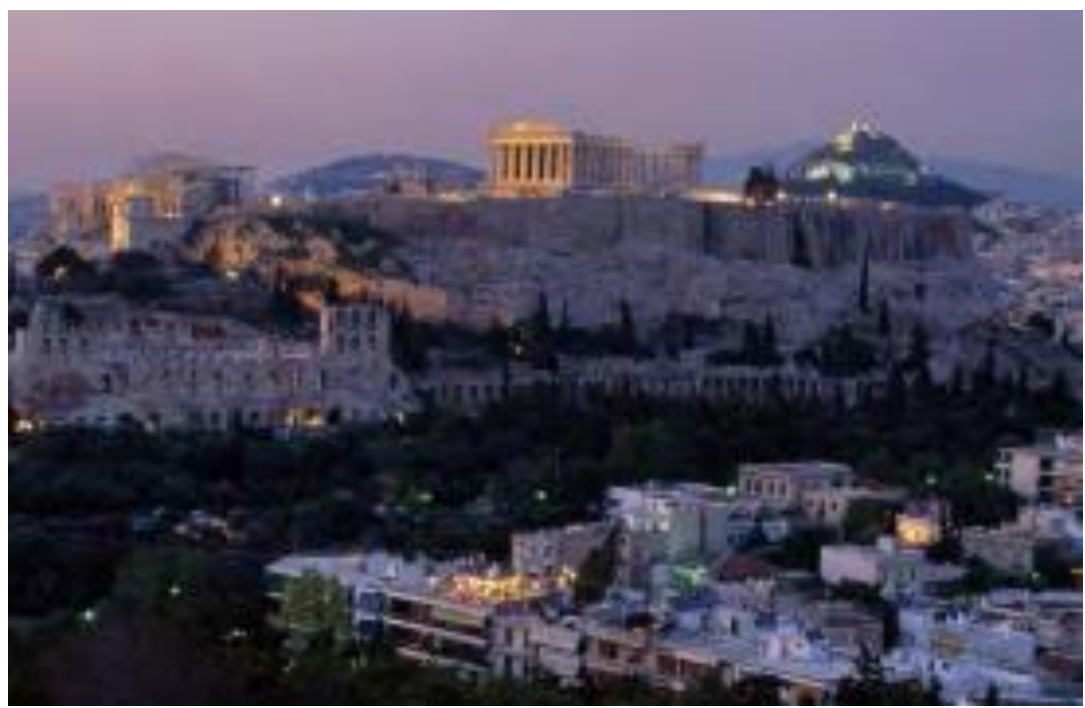

Figure 1: Greece, Athens, Acropolis Collection Overview, World Bank

The early temples were made of wood, and over time, their wooden form gradually changed and durable materials such as limestone and sometimes marble were used. The Greek temple, in terms of layout, closely resembles that of the Barnes Masonic Hall, and even in its most advanced form, the basic simplicity of the Hall's building is to be seen, a single or two roomed room with no 
windows, with one In (two doors for nested) and (a) a porch or two columns between walls (columns between two jars), or (b) posterior columns (wallless columns), or (c) columns Posterior and anterior, or each of these maps, inscribed by (d and e) a row or (and) two rows, (figure 2).

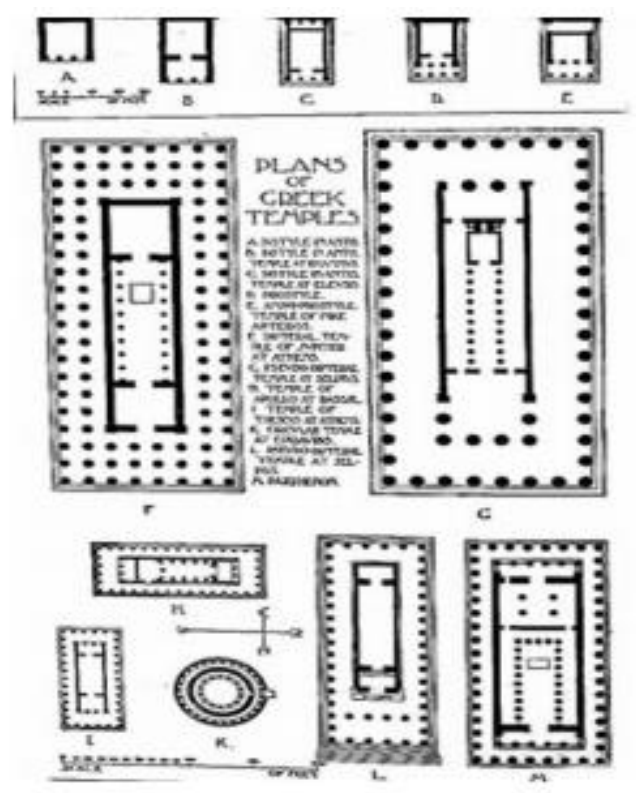

Figure 2:Different types of Greek temples

What we have all seen in ancient Near Eastern architecture: its order and its symmetry, the difference in sense of proportion by the Greeks and their striving for optimal perfection in terms of regular numerical relations and geometrical rules. Their experimentation guides were found to fit into the maps of temples. The earlier temples (of ancient times) were often narrow and had a ratio of approximately one to three between the posterior and anterior walls.

Late Classical and Hellenistic maps were closer to one-two, but never exactly one-two; lateral walls of the Classical period were often slightly more than twice the posterior and anterior walls. Appropriation in architecture, sculpture and harmony in music was almost a unifying phenomenon in the Greek mind and, in a more accurate sense, embodied cosmic order, as "good life" and rationality did. The long description of the Greek building is expressed from top to bottom with the terms column, platform and superstructure or spray; this is how the composition and the relationships 
between the three components or units are called. The three ways that Greek architects developed were somewhat different in detail, but largely in terms of the relative proportions of the components. Each method was used for a specific purpose and embodied different concepts. The earliest formulable practices in Greek architecture were the Durrican style of Greek mainland and the Ionic style of Central Asia and the Aegean islands of the Corontian style, later found. Stones mounted on a ramp or platform. Depending on the type of each method, it consists of two or three components: the column body, whose surface is covered with vertical slots (spoons). The head of the column and (in Unicentric and Corinthian way) the pedestal or base of the column, the height of the column body gradually decreases as the column diameter decreases and a slight curvature in its profile (convexity convex); Is characterized by one or more horizontal
801

lines (Sereston's throat) which are the forerunner to Sereston. The column is composed of two components, the lower part being cushioned in style; It is small in the Unicode style and under the base sometimes leads to a spiral-like spiral and is added in a Corinthian manner for its height and is essentially The spray is made up of three parts: the fringe or backrest and the main compressor mounted directly on the headstock; the inscription, and the prominent, horizontal edge of the roof with the other two inclined triangles forming the santuri. Includes itself. In the Ionic and Cornite styles, the fringe border is often divided into three rows of molded overlays.

The inscription in Durrick's style is divided into two parts, three compositions and four corners, and in the unicorn's manner it remains unified to provide a unified context for prominent roles (figure 3). 


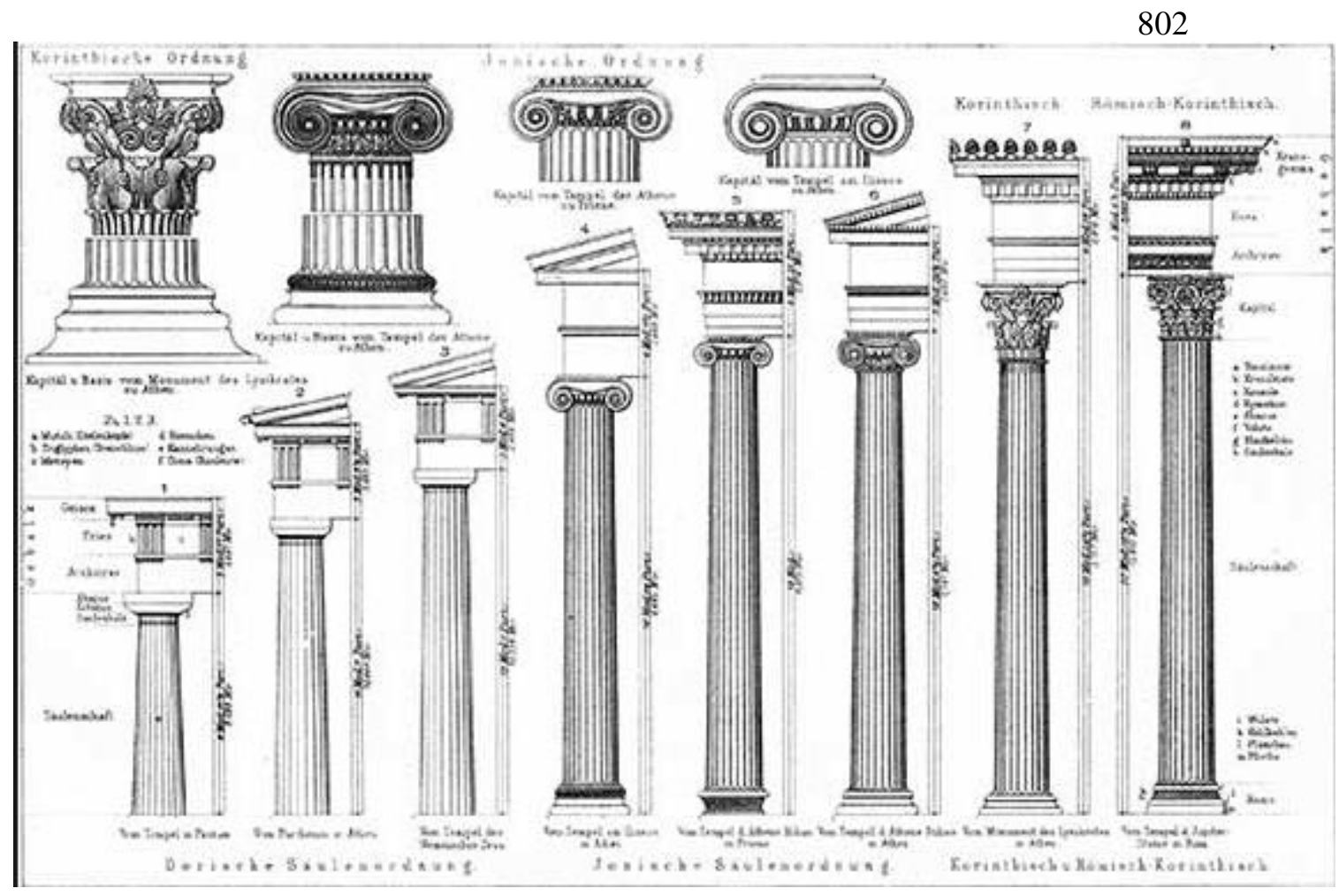

Figure 3: Types of Greek styles and comparisons them

\section{Case examples (Nisa City)}

The relics and survivors of Nisa where was an ancient settlement of the Iranian peoples, located near (modernday) Bagir village, $18 \mathrm{~km}$ southwest of Ashgabat, Turkmenistan. Nisa is described by some as the first seat of central government of the Parthians. It is traditionally assumed to have been founded by Arsaces I (reigned c. 250 $\mathrm{BC}-211 \mathrm{BC}$ ) and was reputedly the royal residence of the Parthian kings, although it has not been established that the fortress at Nisa was either a royal residence or a mausoleum. Many monuments have been identified with separate plans. The Nisa Basin in Turkmenistan today is one of the most important cities and many believe that this city is in fact one of their first capitals. 


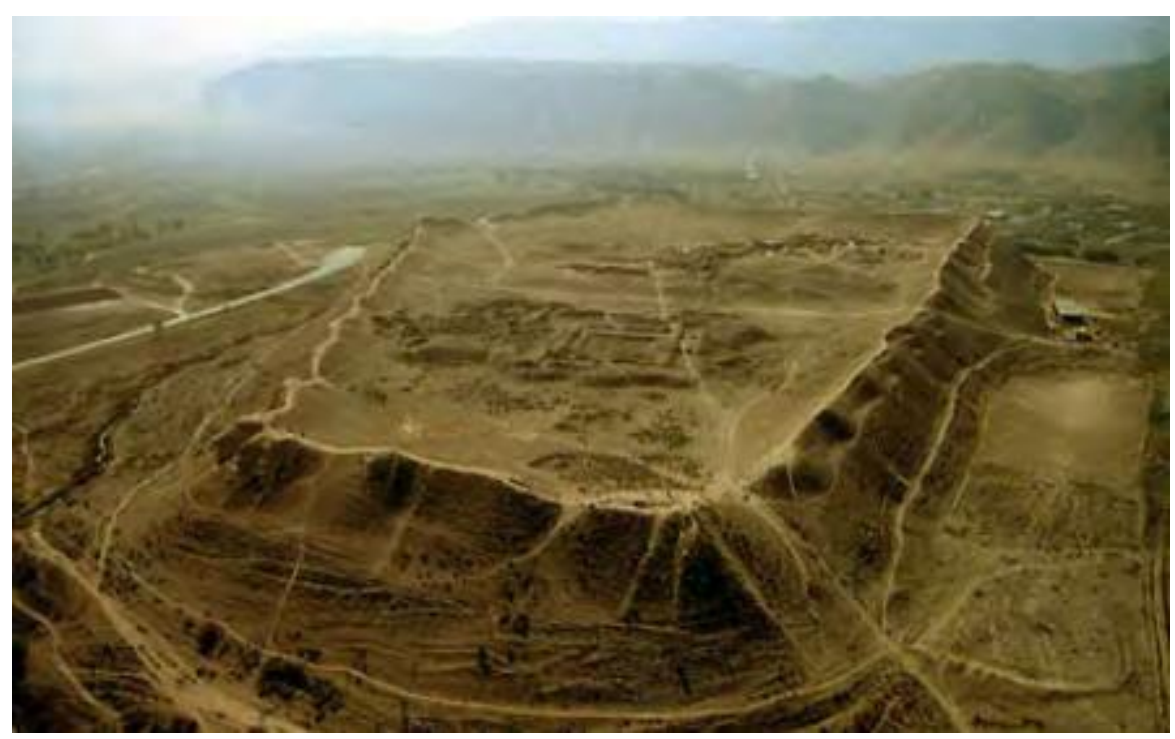

Figure 4: Nisa aerial image

The geographical location of the city of Nisa placed it at the crossroads of four major commercial routes. The Parthian Empire used the city as an obstacle to the advancement of the Romans, but at the same time it was a very important point of contact between East, West, North and South. The area is well-known for its Greek art and culture. The ancient site of Nisa now comprises two distinct parts: the city of Nisa, the new and the old. Research has shown that the new city of Nisa was one of the most important cities of the region in its time, flourishing at least to the Parthian period and surviving to the mid-century.

But the holy city of Nisa, within the fences, towers and fences, had a complex of public and ceremonial buildings and was an important religious and governmental center for the Parthian kings. In fact, the new city was home to most of Nisa's people and the old city was home to the royal citadel and ritual and religious buildings. The old town or royal citadel stands on 14 hectares of natural hills and is surrounded by forty towers. There are numerous buildings with different uses in this part of the ancient city. One of these buildings, which has a large courtyard, has several rooms, each of which has its own purpose: a royal treasury, a wine cellar, and a side building. 




Figure 5: Topographic map of Nisa's Old Town

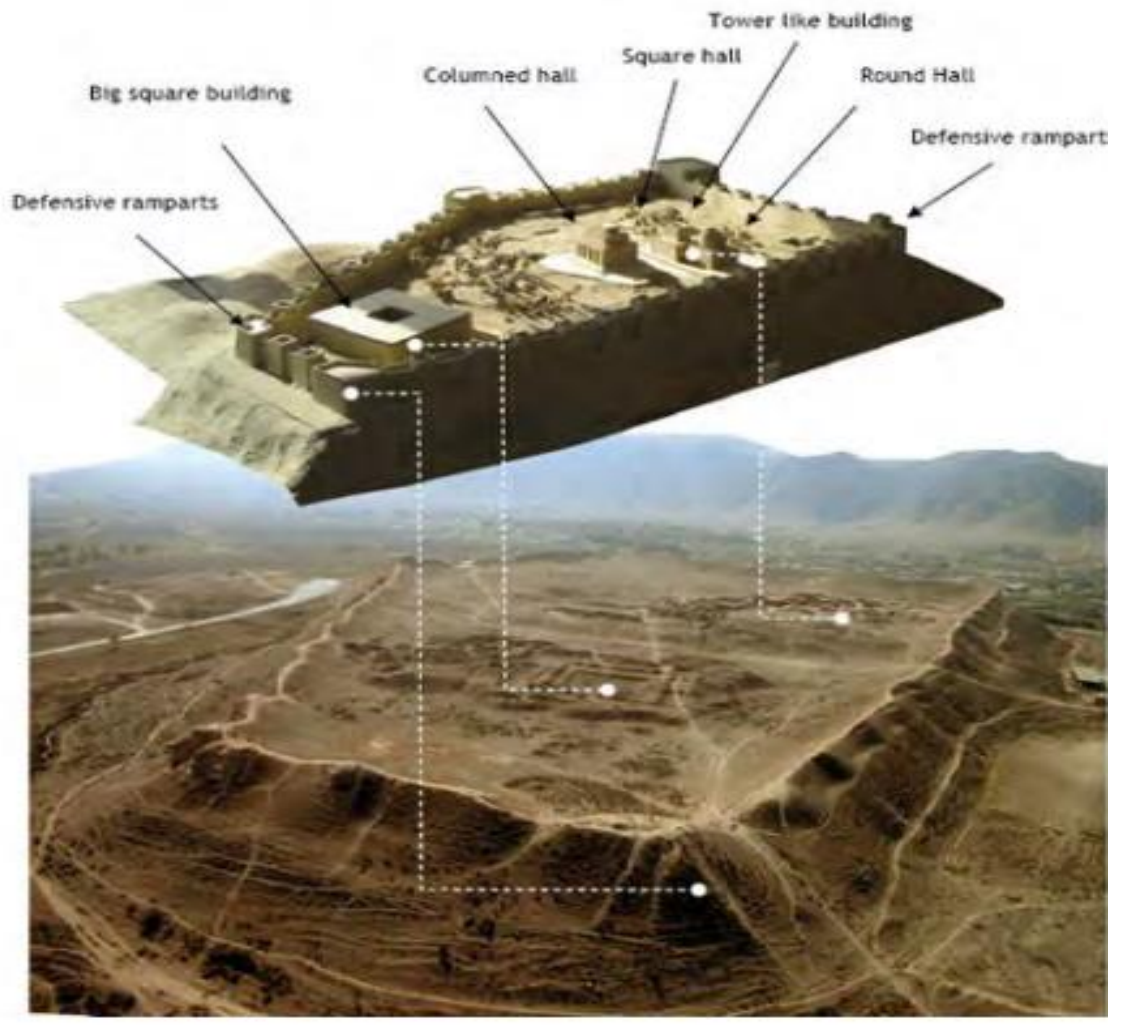

figure 5 - The supposed restoration of the old city of Nisa 


\section{Town of Parthian period:}

Parthian government body with the destruction of the Seleucid government, embodies the Hellenistic city of Pars have also changed and for the first time in history, the city creates circular. Four major city in the Parthian period and was restored, and all four were circular in design, are: Mary, Ctesiphon, Hatra (Altar) and City Shays (Takht-e Soleiman current) of Ctesiphon was the first military camp that the Roman side was created. City Hydra (Altar) in the same order on the border of Mesopotamia (in the Parthian era) was built.

\section{Conclusion:}

Parthians had for 475 years of monarchy in Iransince $250 \mathrm{BC}$. AD to 226 AD began and ended. Contact Party ring style architecture and art with architecture and art of the Achaemenes era Sassanid era.Art of Alien and delivered to the Iranians. Greek architecture could survive in Iran. Because not only Greece's model was not accepted but Greek and Roman materials that rock and is abundant. This material is not in use, because the region does not have adequate coordination of the use of these materials. Another feature of this era of self-sufficiency and the use of ecological materials is achieved. In general we can say that the architecture of Parthian era have gradually from under whatever was imposed on Iranian art and flavor out of Iran to take, Because of the nature of the Iranian Parthian architectural style once again to praise his occupation is construction. Given that this process eventually culminating Sassanid architecture ancient architecture led Iran.

\section{References}

Khan Santa expression and Queen Malekzadeh, the first throne Part, historical studies, twelfth year, No. 12, p: 110, 2016.

Shakur, M.J. and Nia Mahmoud Rajab, 1995. political and social history of the Parthians, Tehran, the world of book publishing, pp: 105.

\section{Ali Akbar stood tall and February} Firouzmandi, 2006. archeology and art history of the Median, Achaemenes, Parthian, Sassanid, Tehran, publishing Malik, first edition, p: 204. 
Jacob Mohammad far, 2010. archeology and art of the Parthian, Tehran, culture and Islamic Guidance, second edition, p: 68.

Arthur Pope, 2003. architect of Iran, Ghulam Hossein Sadri translated Ansari, Tehran, stars, 47. Jacob Mohammad far, p: 68.

Ferreira, W., 1995. the art of Iran, Pervez translator border, Tehran, Ferzan Publications, p: 57. Ibid., p: 63.

Hussein Zmrshydy, 2008. arches and arch in architecture, Tehran, Iran's Civil and Urban Development, p: 25.

Pervez border, 2007. abstract art, Tehran, Scientific and Cultural Publications, fourteenth edition, p: 36. Houshang messenger, 2005. history and architectural style, Tehran, Pshvtn Publishing, p: 40.

Parviz border, p: 36 . Hushing messenger, p: 40. Maria Brvsyvs, 2010. ancient Iranians, translation Mani Saleh, Tehran, Sales Publishing, p: 171.
Hassan Habibie, 2006. the flux of the city, Tehran, Tehran University

Publishing, p: 25 